\title{
A Family Study of Atrial Septal Defect
}

\author{
ELSPETH M. WILLIAMSON
}

\author{
From Southampton Children's Hospital, Southampton
}

Family studies, largely based on questionnaires, of patients suffering from atrial septal defect have shown a small but significant increase in the number of close relatives affected by congenital heart malformation (Campbell and Polani, 1961; Lamy, de Grouchy, and Schweisguth, 1957). A more recent family study, where available parents and sibs of affected patients were interviewed and clinically examined, revealed a higher proportion of affected relatives (Nora, McNamara, and Fraser, 1967b). A further series seemed worth while, particularly one giving information on the occurrence of cardiac malformation in offspring of patients with atrial septal defect. The results of such a study are reported here.

\section{Method and Material}

Records of the Wessex Cardiothoracic Centre were searched and an attempt was made to trace those patients who had attended the Centre during the period January $1960-1966$, in whom the diagnosis of atrial septal defect was made by clinical methods and electrocardiographic findings, and confirmed by cardiac catheterization, surgery, or necropsy. Those living far overseas were excluded, as were those patients who had died and whose parents were not available for interview. A particular effort was made to trace adult patients in order to gain information about their offspring. To obtain a homogeneous group, patients were excluded if a final diagnosis of ostium primum defect was reached, or if the atrial septal defect formed only a minor component of a more complex lesion.

Eventually 136 patients were invited to participate in the study. One did not wish to co-operate, so 135 patients from 131 families were included as index patients. These patients and their families were visited and a full social and family history elicited. Wherever possible, parents, sibs, and offspring were examined. No relative was included as suffering from congenital heart malformation unless there was confirmatory evidence from hospital records or death certificate.

The index patients were grouped according to the cardiological diagnosis (Table I).

Received March 4, 1969.
TABLE I

CARDIAC MALFORMATION IN INDEX PATIENTS

\begin{tabular}{|c|c|c|c|}
\hline & Total & Male & Female \\
\hline $\begin{array}{l}\text { Group I: ostium secundum defect only } \\
\text { Group II: ostium secundum defect with } \\
\text { other cardiovascular anomaly } \\
\text { Group III: sinus venosus type defect }\end{array}$ & $\begin{array}{l}99 \\
25 \\
11\end{array}$ & $\begin{array}{r}30 \\
10 \\
7\end{array}$ & $\begin{array}{r}69 \\
15 \\
4\end{array}$ \\
\hline Total index patients & 135 & 47 & 88 \\
\hline
\end{tabular}

Group I comprised 99 patients ( 30 male and 69 female) in whom an ostium secundum defect was the only cardiovascular malformation.

Group II comprised 25 patients (10 males and 15 female) in whom an ostium secundum defect was associated with some other cardiovascular abnormality. Anomalous venous drainage, pulmonary valve stenosis, and ventricular septal defect were the most common associated anomalies, but aortic coarctation, persistent ductus arteriosus, mitral stenosis, and subaortic stenosis were also found.

Group III comprised 11 patients ( 7 male and 4 female) in whom a sinus venosus type defect was diagnosed. These were all associated with some degree of anomalous venous drainage.

A female preponderance was found among the index patients, giving a sex ratio of 0.53 . This preponderance was most marked among the patients with isolated secundum defects.

Associated Non-cardiac Malformations in Index Patients. One index patient had Down's syndrome and two were educationally subnormal. Three children had strabismus, one had accessory nipples, and one accessory auricles. One child had had an operation for pyloric stenosis. Minor skeletal abnormalities included two bifid ribs in a boy, and triphalangeal, finger-like thumbs in a girl, similar to those described by Holt and Oram (1960) associated with atrial septal defect. Neither the parents nor the sibs of this index patient had a similar thumb or cardiac abnormality.

Twins. Four of the index patients were one of twins; in no case was the co-twin affected. One pair was of unlike sex and one female pair was known to be dizygotic. In the other two female pairs there was insufficient evidence to determine zygosity. 


\section{Results}

Summaries of the families are given in Appendixes $A, B$, and $C$.

(1) 78 Index Patients whose Mothers were Interviewed. These index patients were distributed as follows. Group I: 53 patients (20 male and 33 female); Group II: 19 patients (10 male and 9 female); Group III: 6 patients (5 male and 1 female).

Maternal and Environmental Factors. The distribution of index patients by maternal age and birth order (Tables II and III) was compared with the Registrar General's figures for the relevant year of birth. (The index patient with Down's syndrome was excluded because of the known association between this syndrome and high maternal age.) The results showed no significant variation from the expected distribution.

The social class of each index patient was determined by the father's employment according to the Registrar General's classification of occupation (1960). A high proportion of parents in the armed services was noted, due probably to the presence of large naval and military bases within the region, but no other significant variation from the distribution in the general population was noted (Table IV).

The season of birth of each index patient was tabulated (Table V). The results showed no variation from the expected distribution.

Maternal health during the relevant pregnancy: during the first trimester of pregnancy two mothers had rubella and one had measles. Vaginal bleeding was reported by two mothers during early pregnancy $(2.6 \%)$. This is similar to the finding of Turnbull and Walker (1956) of $2-4 \%$ threatened abortion in all pregnancies. One mother admitted trying to procure an abortion with purgatives.

Sibs of These 78 Index Patients. Stillbirths, abortions, normal, and affected sibs occurring within the family (excluding the index patient) are tabulated in Table VI. The figures have been scrutinized, and no significant differences are revealed in the results of the pregnancies before the index patient and those after the index patient; nor were there differences between the families where the index patient was male and the families where the index patient was female. Thus the total figures are considered. The 212 pregnancies resulted in 22 abortions $(10 \cdot 3 \%)$. This figure does not differ significantly

TABLE II

MATERNAL AGE AT BIRTH OF INDEX PATIENTS

\begin{tabular}{|c|c|c|c|c|c|c|c|c|}
\hline $\begin{array}{c}\text { Maternal } \\
\text { Age (yr.) }\end{array}$ & $<20$ & $20-24$ & $25-29$ & $30-34$ & $35-39$ & $40+$ & & Total \\
\hline Group & $2 \cdot 1$ & $\begin{array}{c}20 \\
15 \cdot 1583\end{array}$ & $\begin{array}{c}9 \\
16 \cdot 2804\end{array}$ & $\begin{array}{c}15 \\
10 \cdot 4733\end{array}$ & $\begin{array}{c}6 \\
5.5153\end{array}$ & $\begin{array}{c}1 \\
1 \cdot 6890\end{array}$ & $\begin{array}{l}\text { Observed } \\
\text { Expected }\end{array}$ & $\begin{array}{l}52 \\
52\end{array}$ \\
\hline$\underset{\text { II }}{\text { Group }}$ & $\begin{array}{c}2 \\
1 \cdot 2736\end{array}$ & $\begin{array}{c}2 \\
5 \cdot 7263\end{array}$ & $\begin{array}{c}6 \\
6 \cdot 0266\end{array}$ & $\begin{array}{c}5 \\
3 \cdot 6450\end{array}$ & $\stackrel{2}{2} 1 \cdot 7846$ & $\stackrel{2}{2} 0.5439$ & $\begin{array}{l}\text { Observed } \\
\text { Expected }\end{array}$ & $\begin{array}{l}19 \\
19\end{array}$ \\
\hline Group & $\begin{array}{c}0 \\
0.3457\end{array}$ & $\frac{1}{1 \cdot 7534}$ & $\begin{array}{c}2 \\
1 \cdot 9273\end{array}$ & $\frac{1}{1 \cdot 1373}$ & $\begin{array}{c}1 \\
0.6399\end{array}$ & $\begin{array}{c}1 \\
0 \cdot 1964\end{array}$ & $\begin{array}{l}\text { Observed } \\
\text { Expected }\end{array}$ & $\begin{array}{l}6 \\
6\end{array}$ \\
\hline Total & 4.53030 & $\begin{array}{c}23 \\
22.6380\end{array}$ & $\begin{array}{c}17 \\
24 \cdot 2343\end{array}$ & $\begin{array}{c}21 \\
15 \cdot 2556\end{array}$ & $\begin{array}{c}9 \\
7.9398\end{array}$ & $\begin{array}{c}4 \\
2 \cdot 4293\end{array}$ & $\begin{array}{l}\text { Observed } \\
\text { Expected }\end{array}$ & $\begin{array}{l}77 \\
77\end{array}$ \\
\hline
\end{tabular}

TABLE III

PARITY OF MOTHERS AT BIRTH OF INDEX PATIENTS

\begin{tabular}{|c|c|c|c|c|c|c|c|c|}
\hline & \multicolumn{6}{|c|}{ Previous Live Births } & & \multirow[b]{2}{*}{ Total } \\
\hline & 0 & 1 & 2 & 3 & 4 & $5+$ & & \\
\hline $\begin{array}{c}\text { Group } \\
\text { I }\end{array}$ & $\begin{array}{c}19 \\
20 \cdot 826\end{array}$ & $\begin{array}{c}13 \\
15 \cdot 559 \\
\end{array}$ & $\begin{array}{c}9 \\
7 \cdot 790 \\
\end{array}$ & $\begin{array}{c}5 \\
3.681\end{array}$ & $\frac{1}{1 \cdot 842}$ & $\begin{array}{c}5 \\
2 \cdot 302\end{array}$ & $\begin{array}{l}\text { Observed } \\
\text { Expected }\end{array}$ & $\begin{array}{l}52 \\
52\end{array}$ \\
\hline $\begin{array}{c}\text { Group } \\
\text { II }\end{array}$ & $\begin{array}{c}7 \\
7 \cdot 403 \\
\end{array}$ & $\begin{array}{c}8 \\
5.651 \\
\end{array}$ & $\begin{array}{c}3 \\
2 \cdot 957\end{array}$ & $\begin{array}{c}1 \\
1 \cdot 433\end{array}$ & $\begin{array}{c}0 \\
0.715\end{array}$ & $\begin{array}{c}0 \\
0.841\end{array}$ & $\begin{array}{l}\text { Observed } \\
\text { Expected }\end{array}$ & $\begin{array}{l}19 \\
19\end{array}$ \\
\hline $\begin{array}{c}\text { Group } \\
\text { III }\end{array}$ & $\begin{array}{r}3 \\
2 \cdot 379 \\
\end{array}$ & $\stackrel{2}{1 \cdot 845}$ & $\begin{array}{c}0 \\
0.901\end{array}$ & $\begin{array}{c}0 \\
0.414 \\
\end{array}$ & $\begin{array}{c}0 \\
0 \cdot 205 \\
\end{array}$ & $\begin{array}{c}1 \\
0.256 \\
\end{array}$ & $\begin{array}{l}\text { Observed } \\
\text { Expected }\end{array}$ & $\begin{array}{l}6 \\
6 \\
\end{array}$ \\
\hline Total & $\begin{array}{c}29 \\
30 \cdot 608\end{array}$ & $\begin{array}{c}23 \\
23 \cdot 055\end{array}$ & $\begin{array}{c}12 \\
11 \cdot 648\end{array}$ & $\begin{array}{c}6 \\
5 \cdot 528\end{array}$ & $\begin{array}{c}1 \\
2 \cdot 762\end{array}$ & $\begin{array}{c}6 \\
3 \cdot 399\end{array}$ & $\begin{array}{l}\text { Observed } \\
\text { Expected }\end{array}$ & $\begin{array}{l}77 \\
77\end{array}$ \\
\hline
\end{tabular}


TABLE IV

SOCIAL CLASS OF INDEX PATIENTS

\begin{tabular}{l|c|r|r|r|r|c}
\hline & \multicolumn{5}{|c|}{ Social Class } & Armed \\
\cline { 2 - 5 } & I & II & III & IV & V & Forces \\
\hline Group I & 2 & 12 & 22 & 10 & 1 & 6 \\
Group II & 0 & 5 & 5 & 5 & 1 & 3 \\
Group III & 0 & 0 & 5 & 0 & 0 & 1 \\
\hline Total & 2 & 17 & 32 & 15 & 2 & 10 \\
\hline $\begin{array}{c}\text { General population } \\
\text { (Southampton) }\end{array}$ & 1.98 & 10.21 & $37 \cdot 72$ & 7.55 & 10.54 & \\
\hline
\end{tabular}

TABLE V

SEASON OF BIRTH OF INDEX PATIENTS

\begin{tabular}{l|c|c|c|c}
\hline & Jan.-Mar. & Apr.-June & July-Sept. & Oct.-Dec. \\
\cline { 2 - 4 } Group I & 9 & 19 & 11 & 14 \\
Group II & 5 & 4 & 3 & 6 \\
Group III & 0 & 0 & 2 & 4 \\
\hline Total & 14 & 23 & 16 & 24 \\
\hline
\end{tabular}

from the $15 \%$ estimated as the expected abortion rate among all pregnancies by Warburton and Fraser (1964). Seven stillbirths resulted from the 190 pregnancies that proceeded beyond 28 weeks' gestation; two of these were due to non-cardiac malformation (one anencephalic and one meningomyelocele), two were due to toxaemia in the mother, two were due to obstetric trauma, and in one case the cause was unknown.

Besides the two stillbirths due to major malformation of the central nervous system, one sib had a severe scoliosis, one had a cleft palate, and one had Down's syndrome. Five instances of major mal- formations among 190 sibs $(2 \cdot 6 \%)$ is similar to the random expectation of about $2.5 \%$ of all births (McKeown and Record, 1960).

There were 12 sibs ( 5 male and 7 female) found to have a congenital cardiac lesion among the 190 $(6.3 \%)$. Four families each had two affected children. In two of these families the lesion was identical; two sisters had an ostium secundum defect and a small ventricular septal defect (No. 71 and 72), and a brother and sister had ostium secundum defects (No. 16 and 45). In a third family the lesions were similar, a girl with an isolated secundum defect and her brother with a similar septal defect and an associated aortic coarctation (No. 34 and 60). In the fourth family, the index patient (No. 47) had an isolated ostium secundum defect and her brother had a ventricular septal defect. In a further family there were six affected children. The index patient (No. 17) had an ostium secundum defect, one brother and one sister had atrial and ventricular septal defects, one brother had a ventricular septal defect with mitral stenosis, and a further brother had a ventricular septal defect with coarctation of the aorta. A fourth brother had left ventricular cardiomyopathy.

Among the 17 half-sibs of index patients, one was affected with a cardiac malformation. The male index patient (No. 54) with a secundum defect and subaortic stenosis had a paternal half-brother with subaortic stenosis.

\section{(2) Findings in Series as a Whole.}

Sibs of Remaining Index Patients. The other 57 index patients (12 male and 45 female) were

TABLE VI

RESULTS OF PREGNANCIES IN MOTHERS OF INDEX PATIENTS

\begin{tabular}{|c|c|c|c|c|c|c|c|}
\hline \multirow{2}{*}{$\begin{array}{l}\text { Sex of } \\
\text { Index } \\
\text { Patient }\end{array}$} & & \multirow{2}{*}{ Stillborn } & \multirow{2}{*}{ Abortion } & \multicolumn{2}{|c|}{ Unaffected Sibs } & \multicolumn{2}{|c|}{ Affected Sibs } \\
\hline & & & & Male & Female & Male & Female \\
\hline $\begin{array}{l}\text { Group } \\
\mathbf{M} \\
\mathbf{F} \\
\text { Group } \\
\mathbf{F} \\
\text { Group } \\
\text { and F }\end{array}$ & $\begin{array}{l}\text { I Born before index patient } \\
\text { Born after index patient } \\
\text { Born before index patient } \\
\text { Born after index patient } \\
\text { II } \\
\text { Born before index patient } \\
\text { Born after index patient } \\
\text { Born before index patient } \\
\text { Born after index patient } \\
\text { III } \\
\text { Born before and after } \\
\text { index patient }\end{array}$ & $\begin{array}{l}1 \\
0 \\
1 \\
0 \\
3 \\
0 \\
1 \\
0 \\
1\end{array}$ & $\begin{array}{l}6 \\
1 \\
4 \\
4 \\
2 \\
0 \\
3 \\
2 \\
\\
\end{array}$ & $\begin{array}{r}24 \\
10 \\
21 \\
15 \\
2 \\
2 \\
4 \\
0 \\
6\end{array}$ & $\begin{array}{r}17 \\
5 \\
16 \\
23 \\
\\
6 \\
5 \\
3 \\
2\end{array}$ & $\begin{array}{l}4 \\
0 \\
0 \\
3 \\
\\
0 \\
0 \\
0 \\
0 \\
\\
\end{array}$ & $\begin{array}{l}2 \\
0 \\
0 \\
0 \\
\\
1 \\
0 \\
1 \\
1 \\
\\
\end{array}$ \\
\hline & Total pregnancies: 212 & 7 & 22 & 90 & 81 & 7 & 5 \\
\hline Half-s & $\begin{array}{l}\text { ibs } \\
\text { Born before index patient } \\
\text { Born after index patient }\end{array}$ & $\begin{array}{l}0 \\
1 \\
\end{array}$ & $\begin{array}{l}\mathbf{0} \\
\mathbf{0}\end{array}$ & $\begin{array}{l}4 \\
4\end{array}$ & $\begin{array}{l}4 \\
3\end{array}$ & $\begin{array}{l}1 \\
0\end{array}$ & $\begin{array}{l}\mathbf{0} \\
0\end{array}$ \\
\hline & Total pregnancies: 17 & 1 & 0 & 8 & 7 & 1 & $\mathbf{0}$ \\
\hline
\end{tabular}


questioned about their sibs. Close family information was incomplete, but 4 sibs with proven congenital heart malformations were found among 204 known sibs $(1.9 \%)$.

Parental Consanguinity. The parents of index patient No. 127 were first cousins, and those of index patient No. 49 were second cousins. None of the five sisters in the sibships was affected with congenital heart malformation, nor was the one brother.

Offspring of Index Patients. Among the adult index patients, 35 females and 10 males had offspring. They were distributed as follows. Group I: 8 males and 27 females; Group II: 5 females; Group III : 2 males and 3 females.

The results of the pregnancies are tabulated in Table VII. There was a total of 121 pregnancies resulting in 110 live births, 1 stillbirth, and 10 abortions $(8.5 \%)$. Three of these children had non-cardiac congenital malformations, i.e. hydrocephalus, fragilitas ossium, and a giant naevus $(2.7 \%)$. These figures show no significant increase over the expected incidence of stillbirth, abortion, and congenital non-cardiac malformation in the general population.

Congenital cardiac lesions were found in 10 of the 111 offspring ( $9 \%$ ). These 10 affected children (6 male and 4 female) were all among the 82 born to affected mothers, none of the 29 children born to affected fathers being themselves affected. Two mothers with isolated secundum defects (No. 87 and 88) each had an affected daughter, one with an identical lesion to herself and the other with a ventricular septal defect. A mother with a secundum defect and anomalous venous drainage (No. 117) bore a daughter who at necropsy was found to have mitral stenosis, aortic coarctation, and a persistent ductus arteriosus. A mother with a sinus venosus type defect (No. 121) bore a son with a ventricular septal defect, and one mother with an isolated secundum defect (No. 89) bore 5 affected boys and one affected daughter. One of her sons (No. 17) had an identical lesion to hers, and the lesions found in her other offspring have been described earlier in the results section.

Congenital Heart Malformation in Further Relatives. One father and one mother of index patients with ostium secundum defects had identical lesions to their children (No. 15 and 17). One other mother and two fathers had suggestive histories and clinical signs but had not been fully investigated. Among 29 grandchildren, 2 were known to be affected, and in 1063 first cousins one was found to have an ostium secundum defect and another died of congenital heart disease thought to be a septal defect. Among 322 nephews and nieces, one had an ostium secundum defect and another a more complex lesion.

Cardiological Diagnosis in Affected First Degree Relatives. The cardiac lesions found in the 26 affected first degree relatives of index patients are tabulated in Table VIII. In 8 cases the lesion found in the relative was identical to that in the index patient, and in a further 6 relatives it was partially so, an atrial septal defect being found in all these 14 relatives. Among the remaining relatives, 7 had ventricular septal defects, 4 in one family showed left ventricular cardiomyopathy, and 1 had mitral stenosis and aortic coarctation with a patent ductus arteriosus.

\section{Discussion}

Familial aggregation of atrial septal defect is apparent in the results of this family study. A recurrence of congenital heart malformation in $6.3 \%$ of sibs of index patients is a higher rate than was reported by Campbell and Polani (1961) or by Nora et al. (1967b). The recurrence in 9\% of offspring of index patients in this study, and the high rate of recurrence in sibs is partly due to the inclusion of a remarkable family where both mother and son were index patients and there were six affected children (Fig.). In this particular family, left ventricular cardiomyopathy occurred in the father (I.1) and

TABLE VII

OFFSPRING OF INDEX PATIENTS

\begin{tabular}{|c|c|c|c|c|c|c|c|}
\hline \multirow{2}{*}{$\begin{array}{l}\text { Sex of } \\
\text { Index } \\
\text { Patient }\end{array}$} & & \multirow{2}{*}{ Stillborn } & \multirow{2}{*}{ Abortion } & \multicolumn{2}{|c|}{$\begin{array}{c}\text { Unaffected } \\
\text { Offspring }\end{array}$} & \multicolumn{2}{|c|}{$\begin{array}{c}\text { Affected } \\
\text { Offspring }\end{array}$} \\
\hline & & & & Male & Female & Male & Female \\
\hline \multirow[t]{2}{*}{$\begin{array}{l}M \\
F \\
F \\
M \\
F\end{array}$} & $\begin{array}{l}\text { Group I } \\
\text { Group I } \\
\text { Group II } \\
\text { Group III } \\
\text { Group III }\end{array}$ & $\begin{array}{l}0 \\
0 \\
0 \\
0 \\
1\end{array}$ & $\begin{array}{l}0 \\
3 \\
5 \\
0 \\
2\end{array}$ & $\begin{array}{r}14 \\
32 \\
4 \\
4 \\
6\end{array}$ & $\begin{array}{r}10 \\
22 \\
5 \\
1 \\
2\end{array}$ & $\begin{array}{l}0 \\
5 \\
0 \\
0 \\
1\end{array}$ & $\begin{array}{l}0 \\
3 \\
1 \\
0 \\
0\end{array}$ \\
\hline & Total pregnancies: 121 & 1 & 10 & 60 & 40 & 6 & 4 \\
\hline
\end{tabular}


TABLE VIII

CARDIAC MALFORMATION IN FIRST DEGREE RELATIVES OF INDEX PATIENTS

\begin{tabular}{|c|c|c|c|c|}
\hline Sex and Index No. & Identical Malformation & $\begin{array}{l}\text { Malformation Including } \\
\text { Atrial Septal Defect }\end{array}$ & $\begin{array}{l}\text { Malformation Including } \\
\text { Ventricular Septal Defect }\end{array}$ & $\begin{array}{c}\text { Other } \\
\text { Malformation }\end{array}$ \\
\hline $\begin{array}{c}\text { Group I } \\
\text { F } 45 \\
\text { F } 16 \\
\text { F } 34 \\
\text { F } 47 \\
\text { M } 15 \\
\text { F } 87 \\
\text { F } 89 \\
\text { M } 17 \\
\text { Group II F } 71 \\
\text { (ASD and VSD) } \\
\text { F } 72 \\
\text { ASD and VSD } \\
\text { M } 60 \\
\text { (ASD and coarct.) } \\
\text { F } 117 \\
\text { (ASD and AVD) } \\
\text { Group III } 121 \\
\text { F } 121\end{array}$ & $\begin{array}{l}\text { Brother, index patient } 16 \\
\text { Sister, index patient } 45 \\
\text { Father } \\
\text { Daughter } \\
\text { Son, index patient } 17 \\
\text { Mother, index patient } 89 \\
\text { Sister, index patient } 72 \\
\text { Sister, index patient } 71\end{array}$ & $\begin{array}{l}\text { Brother, index patient } 60, \text { ASD } \\
\text { and coarctation of aorta } \\
\text { Son, ASD and VSD; daughter, } \\
\text { ASD and VSD } \\
\text { Brother, ASD and VSD; } \\
\text { sister, ASD and VSD } \\
\text { Sister, index patient 34, ASD }\end{array}$ & $\begin{array}{l}\text { Brother, VSD } \\
\text { Daughter, VSD } \\
\text { Son, VSD and MS; son VSD } \\
\text { and coarct. } \\
\text { Brother, VSD and MS; } \\
\text { brother, VSD and coarct. } \\
\text { Son, VSD }\end{array}$ & $\begin{array}{l}\text { Brother, LVC; } \\
\text { son, LVC; } \\
\text { father, LVC } \\
\text { Brother, LVC } \\
\text { Daughter, MS, } \\
\text { PDA, and } \\
\text { coarct. }\end{array}$ \\
\hline
\end{tabular}

Abbreviations: ASD-atrial septal defect; VSD-ventricular septal defect; MS—mitral stenosis; PDA-patent ductus arteriosus; coarct.coarctation of aorta; AVD-anomalous venous drainage; LVC-left ventricular cardiomyopathy.

brother (II.2) of the index patient and in one of her sons (III.3). McKusick (1964) has described this condition as a single gene affect transmitted as a dominant trait, and this pedigree is consistent with a dominant mode of transmission with reduced penetrance, as there is no evidence of cardiomyopathy in the index patient (II.1). The occurrence of a second, probably unrelated, congenital cardiac disease in this family, and the fact that this one family has contributed so much to the high rates of recurrence in first degree relatives found in this series, make it seem wise not to include this family

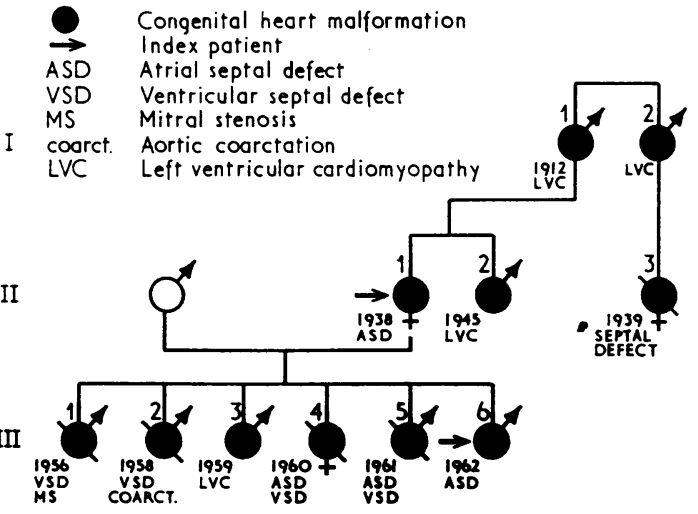

FIG. Pedigree of index patients 17 and 89. for the purpose of calculating the recurrence rates. Excluding this family, recurrence of congenital heart malformation was found in $3.7 \%$ of sibs of index patients (a figure close to the $3.6 \%$ reported by Nora et al., 1967b) and in 3.8\% of offspring of index patients.

Studies of the maternal age and parity at the birth of the index patient and the social class of the family gave no evidence of these environmental factors being involved in the aetiology of atrial septal defect. Landtmann (1965) found an increase in the number of babies born with atrial septal defects in late summer and early autumn, corresponding he suggests with the winter occurrence of acute viral infections, which would affect the mother in early pregnancy. This finding is not confirmed in the present series where no significant trend in the season of birth of the index patients was noted.

The twins in this study showed no concordance for atrial septal defect. Uchida and Rowe (1957) reported no increased concordance for congenital heart malformation among monozygotic twin pairs than among dizygotic pairs. A personal study by Nora et al. (1967a) reported two monozygotic twin pairs where both twins were affected with atrial septal defect, and three dizygotic twin pairs where only one twin was affected with atrial septal defect. Though these figures are small, they support the suggestion that genetic factors are involved in the aetiology of atrial septal defect. 
Some families in the present series (No. 15, 87, 88) suggest a dominant mode of transmission, whereas others (No. 16, 45, 71, 72) suggest a recessive mode. However, the over-all recurrence rate does not support any simple Mendelian pattern. It has been shown that polygenic inheritance can mimic a Mendelian pattern (Edwards, 1960), and it is suggested that the results of the present study can be explained on the hypothesis that the genetic predisposition to atrial septal defect is polygenic.

Similarity of the lesion in affected relatives of patients with atrial septal defect has been noticed in previous reports (Christensen and Nelson, 1963; Carleton, Abelmann, and Hancock, 1958). In the present series, 4 of the 26 affected first degree relatives suffered from left ventricular cardiomyopathy and came from the one family. In the remaining 22 first degree relatives, only 8 showed an identical lesion to the index patient, but $14(63.6 \%)$ had an atrial septal defect. Thus, $63.6 \%$ of the $3.7 \%$ of first degree relatives found to have a congenital cardiac malformation had an atrial septal defect-a recurrence of atrial septal defect in $2.35 \%$ of first degree relatives.

The incidence of congenital heart malformation has been estimated to be about 6 per 1000 births, and in a Liverpool series Hay (1966) found a defect of the atrial septum in $11.7 \%$ of affected babies; the incidence of atrial septal defect, estimated from these figures, is $0.07 \%$ of births. Using the method described by Falconer (1965), with a population incidence of $0.07 \%$ and an incidence in first degree relatives of $2.35 \%$, the heritability of atrial septal defect is about $70 \%(69 \% \pm 9 \%)$.

The sharp fall-off in the proportion of second degree relatives affected is in accordance with polygenic injeritance (Carter, 1961, 1969), and is in contrast to the expected even halving of the proportion affected with each degree of relationship, if a dominant gene with a reduced penetrance were involved. A deviation from the normal sex ratio with a preponderance of females was found, as in previous studies (Campbell and Polani, 1961). There is, however, no evidence from the families now reported, that the relatives of the less commonly affected sex are more at risk than those of the commonly affected sex, but the male deficit is not large enough for any considerable increase in risk to be expected.

With polygenic inheritance, the risk of the abnormality occurring within a family is increased if there are affected close relatives. The large family in the present series, in which a mother and five of her children have septal defects, and the families described by Nora et al. (1967b) and by Campbell and
Polani (1961) with many affected members, could represent families where many of the predisposing genes are concentrated.

Two consanguineous marriages among the parents of 135 index patients is possibly higher than expected in the general population, but is compatible with polygenic inheritance (Carter, David, and Laurence, 1968). None of the 6 sibs of the consanguineous sibship was affected with atrial septal defect, so there was no recessive subgroup detectable by parental consanguinity in this series. It has been suggested that recurrence of anomalies within a sibship is as likely to be due to persistence or recurrence of environmental factors as to a common genetic inheritance (Yen and MacMahon, 1968). The finding in the present series of recurrence of atrial septal defect as frequently in the offspring of index patients as in their sibs, together with Nora et al. (1967a) reporting a higher concordance in monozygotic twins than in dizygotic twins, indicate that genetic factors are of importance in the aetiology of atrial septal defect. The figures presented in this paper on the familial occurrence of atrial septal defect can be explained by polygenic inheritance.

\section{Summary}

Results of a family study of 135 index patients suffering from congenital atrial septal defect are reported.

Maternal age and parity, maternal health during ? pregnancy, season of birth, and social class studies gave no evidence of these environmental factors being involved in aetiology.

In all, $3.7 \%$ of sibs and $3.8 \%$ of offspring of index patients were affected with congenital heart malformation, the cardiac lesion being an atrial septal defect in $63 \%$ of affected first degree relatives. The heritability is estimated at $70 \%$. These findings are compatible with the hypothesis that the predisposition to atrial septal defect is polygenic.

Thanks are due to Dr. Alan Johnson, Wessex Cardiothoracic Centre, and to Dr. Cedric Carter, M.R.C. Clinical Genetics Unit, Institute of Child Health, for help and advice in the preparation of this paper; to the physicians and surgeons of the Wessex Cardiothoracic Centre for access to their case reports; and to the regional general practitioners for allowing me to visit their patients.

The family study was supported by a grant from the British Heart Foundation.

\section{REFERENCES}

Campbell, M., and Polani, P. E. (1961). Factors in the aetiology of atrial defect. Brit. Heart f., 23, 477.

Carleton, R. A., Abelmann, W. H., and Hancock, E. W. (1958). Familial occurrence of congenital heart disease. Report of three families and review of the literature. New Engl. F. Med., 259, 1237. 
Carter, C. O. (1961). Congenital abnormalities. In Clinical Aspects of Genetics, p. 30. Ed. by F. Avery Jones. Pitman Medical, London. 52.

(1969). Genetics of common disorders. Brit. med. Bull., 25,

-, David, P. A., and Laurence, K. M. (1968). A family study of major central nervous system malformations in South Wales. $\mathcal{f}$. med. Genet., 5, 81.

Christensen, F. K., and Nelson, R. M. (1963). Similar congenital heart disease in siblings. $\mathcal{f}$. thorac. cardiovasc. Surg., 45, 592.

Edwards, J. H. (1960). The simulation of Mendelism. Acta Genet. (Basel), 10, 63.

Falconer, D. S. (1965). The inheritance of liability to certain diseases, estimated from the incidence among relatives. Ann. hum. Genet., 29, 51.

Hay, J. D. (1966). Population and clinic studies of congenital heart disease in Liverpool. Brit. med. F., 2, 661.

Holt, M., and Oram, S. (1960). Familial heart disease with skeletal malformations. Brit. Heart f., 22, 236.

Lamy, M., de Grouchy, J., and Schweisguth, O. (1957). Genetic and non genetic factors in the aetiology of congenital heart disease. A study of 1188 cases. Amer. F. hum. Genet., 9, 17.
Landtmann, B. (1965). Epidemiological aspects of congenital heart disease. Acta paediat. scand., 54, 467.

McKeown, T., and Record, R. G. (1960). In Ciba Foundation Symposium on Congenital Malformations, p. 5. Ed. by G. E. W. Wolstenholme and C. M. O'Connor. Churchill, London.

McKusick, V. A. (1964). A genetical view of cardiovascular disease. Circulation, 30, 326.

Nora, J. J., Gilliland, J. C., Somerville, R. J., and McNamara, D. G. (1967a). Congenital heart disease in twins. New Engl. $\mathcal{F}$. Med., 277, 568.

-, McNamara, D. G., and Fraser, F. C. (1967b). Hereditary factors in atrial septal defect. Circulation, 35, 448.

Registrar General (1960). Classification of Occupation. H.M.S.O., London.

Turnbull, E. P. N., and Walker, J. (1956). The outcome of pregnancy complicated by threatened abortion. $\mathcal{F}$. Obstet. Gynaec. Brit. Emp., 63, 553.

Uchida, I. A., and Rowe, R. D. (1957). Discordant heart anomalies in twins. Amer. f. hum. Genet., 9, 133.

Warburton, D., and Fraser, F. C. (1964). Spontaneous abortion risks in man. Data from reproductive histories collected in a Medical Genetics Unit. ibid., 16, 1.

Yen, S., and MacMahon, B. (1968). Genetics of anencephaly and spina bifida. Lancet, 2, 623. 
APPENDIX A

Index Patients Whose Mothers Were Interviewed

Abbreviations: sb, stillborn; *, relative affected with congenital heart defect; ASD, atrial septal defect; VSD, ventricular septal defect; MS, mitral stenosis; M. inc., mitral incompetence; PDA, persistent ductus arteriosus; PVS, pulmonary valve stenosis; AVD, anomalous venous drainage; IP, index patient.




APPENDIX A-continued

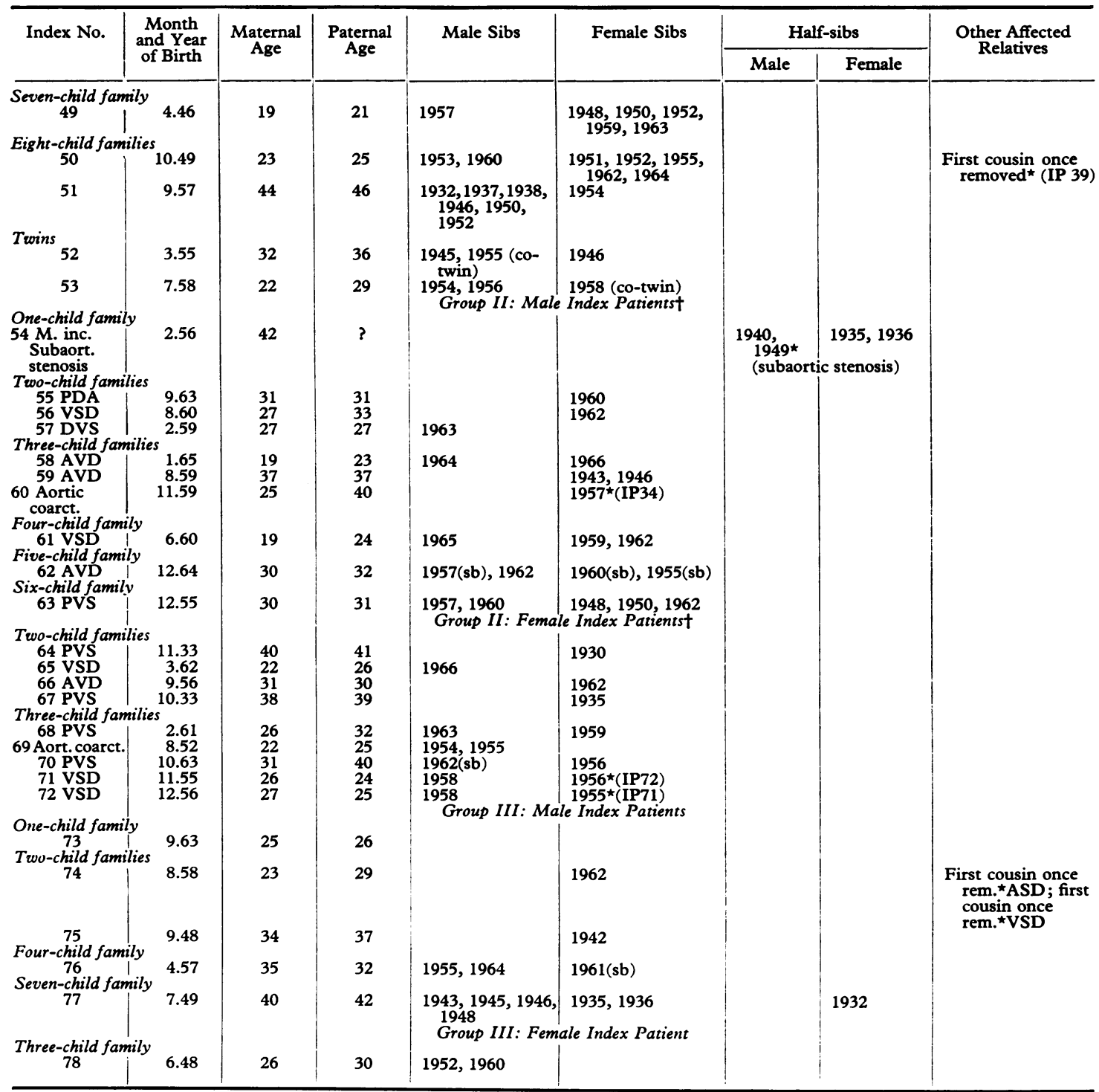

† Associated cardiac lesion is indicated immediately after Index No. 


\section{APPENDIX B \\ Index Patients With Offspring}

Abbreviations: sb, stillborn; *, relative affected with congenital heart defect; ASD, atrial septal defect; VSD, ventricular septal defect; MS, mitral stenosis; M. inc., mitral incompetence; PDA, persistent ductus arteriosus; PVS, pulmonary valve stenosis; AVD, anomalous venous drainage; IP, index patient.

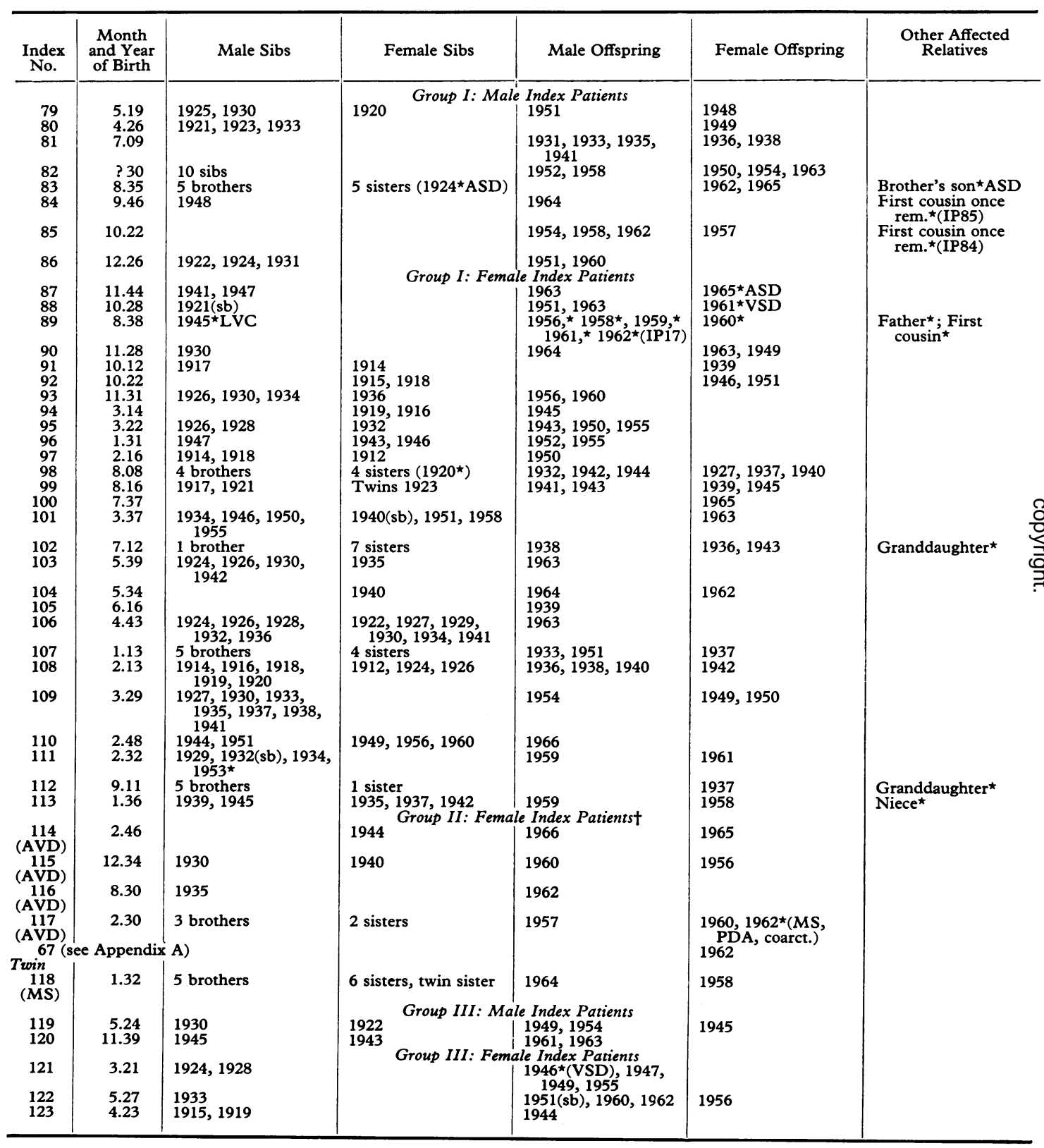

† Associated cardiac lesion is indicated immediately after index No. 
APPENDIX C

Index Patients Without Offspring Whose Parents Were Not Available for Interview

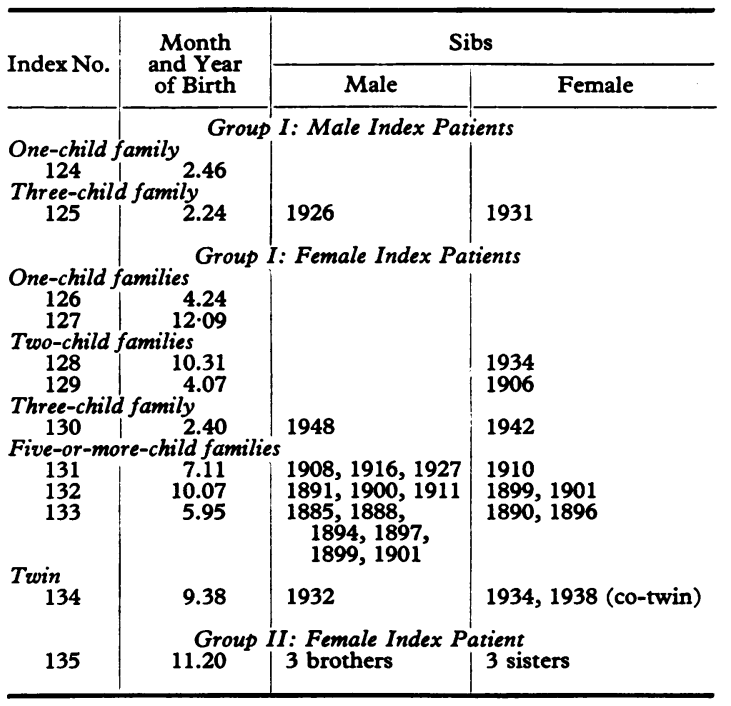

